\title{
Farm Income and Price Trends
}

ET FARM INCOME per farm worker has ad. vanced substantially in recent years. From $\$ 2,700$ per worker in 1960 annual income rose to $\$ 4,800$ per worker in 1966. These figures do not include income of farmers from non-farm employment, or capital gains from increases in value of farm land.

In the first half of 1967 income per worker fell to a $\$ 4,500$ annual rate. Prices received by farmers were well below year-ago levels, reflecting a larger volume of commodities marketed. In recent weeks farm prices have increased, and income prospects for the last half of the year have improved. Also, larger crops are indicated both for the nation and the Central Mississippi Valley states.

Although farm income per farm worker in the first half of this year was down 5 per cent from the 1966 record level, it was still 12 per cent above the level for 1965 and second only to 1966 (Table I). During the six years 1960-66, net farm income per worker rose at an annual rate of 10 per cent. In comparison, nonfarm income per worker rose at the rate of 4 per cent during this period. From 1960 to the first half of 1967 , farm income per worker rose 8 per cent per year com-

Table I

FARM INCOME PER WORKER

United Siates

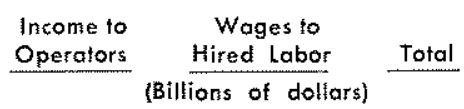

\begin{tabular}{|c|c|}
\hline $\begin{array}{l}\text { Number of } \\
\text { Farm Workers }\end{array}$ & $\begin{array}{c}\text { Income } \\
\text { Per Worker }\end{array}$ \\
\hline (Thousands) & [Dollars] \\
\hline 3,838 & 4,524 \\
\hline 3,979 & 4,767 \\
\hline 4,361 & 4,051 \\
\hline 4,523 & 3,317 \\
\hline 4,687 & 3,423 \\
\hline 4,944 & 3,244 \\
\hline 5,200 & 3,045 \\
\hline 5,458 & 2,726 \\
\hline
\end{tabular}

1 Fírst-half 1967 at annual zate. Soltre: USDA. pared with 4 per cent for nonfarm income. The gains in farm income per worker reflect a sizable net movement of workers from farm to nonfarm employment and a slow increase in total farm income.

Total farm income to operators and labor rose from $\$ 14.9$ billion in 1960 to $\$ 19.0$ billion in 1966 , a 4 per cent annual rate of increase. Rapidly advancing technology has steadily reduced not only the proportion but the number of workers employed on the farm. Farm income in 1960 was shared by 5.5 million farm workers, whereas in 1966 it was shared by 4.0 million workers and by only 3.8 million in the first half of 1967. Farm workers declined 250 thousand per year during the six years $1960-66$, or about 5 per cent per year.

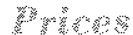

Fluctuation of prices for farm commodities was the chief factor in the reduced income in the first half of this year. Cash receipts during the first five months were down about 2 per cent from year-earlier levels, a net result of substantially lower prices and a larger volume of products marketed. Costs of production continued upward at about the same rate as in recent years.

Farm commodity prices were 5 per cent lower in the first half of the year than during the corresponding months a year earlier. Livestock product prices were down 6 per cent and crops 4 per cent (Table II). In the livestock sector, hog prices dropped 21 per cent, while broiler and egg prices declined 14.6 and 15.4 per cent, respectively. Lower prices for cotton and soybeans were important in reducing the average for the crop sector.

Farm commodity prices have turned upward in recent weeks, pointing to higher farm incomes in 
Toble 11

\section{FARM COMMODITY PRICES}

Hogs, per cwl.

Beef catlie, per cwt.

Milk, wholesale, per cwt.

Broilers, live, par lb.

Eggs, per dozen

Colton, per lb.

Wheat, per bu.

Soybeans, per bu,

Corn, per bu.

Rice, per ewt.

All livestock products 1

Al] erops $^{1}$

All farm cammodities

1 Averages of price indexes $(1910-14=100)$.

Source: USDA Agricalitatal Prices.

the second half of the year. Prices in mid-June had risen 4 per cent from the mid-April low, and recent daily quotes on major commodities indicate some further price increases from mid-June to late July.

Although prices received by farmers averaged lower the first six months of this year than a year ago, they were still well above levels for most recent years. For example, prices in the first half of this year were 5 per cent above the 1957-59 average, 2 per cent higher than in 1965,7 per cent higher than in 1964, and higher than the average for any year from 1953 to 1965, inclusive.

\section{Fraturism}

The lower farm product prices and the decline in farm income this year were caused by an increase in volume of products marketed. The increase in production was more than offset by the resulting price declines. Livestock producers responded to favorable 1966 prices by stepping up production. Red meat (beef, veal, lamb, mutton and pork) output during January-May inclusive was 9 per cent above the comparable months in 1966 (Table III). Pork production increased 16 per cent, beef, 6 per cent, and chickens, 8 per cent. Milk output, however, remained about unchanged.

The price declines in the crop sector reflected larger crops of citrus fruits and of some commercial vegetables, increased supplies of soybeans, and changes in the loan rate on cotton. A smaller supply of feed, coupled with a reduction in export demand, resulted in generally stable feed prices. A shrinkage in food grain supplies had little impact on prices because of the large quantity in storage. The heavy wheat harvest this year resulted in declining prices at mid-year.

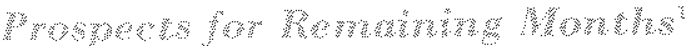

After adjustment for seasonal influences, cash farm receipts are likely to average somewhat higher in the last half of the year than in the first half. Production of livestock seems to be slowing, and prices are expected to rise sufficiently to bring about a higher return. Poultry sales slackened somewhat in June. Egg settings indicate some decline in broiler production during July-August to about last year's level, compared with an 8 per cent increase in production in the first five months of 1966. Egg production, which was 6 per cent above last year's level in the first half of the year, will probably lose momentum in the second half. Fall hog slaughter rates are expected to drop below those

${ }^{1}$ Summary of USDA outlook reports as of mid-1967.

\section{Prices Received by Farmers}

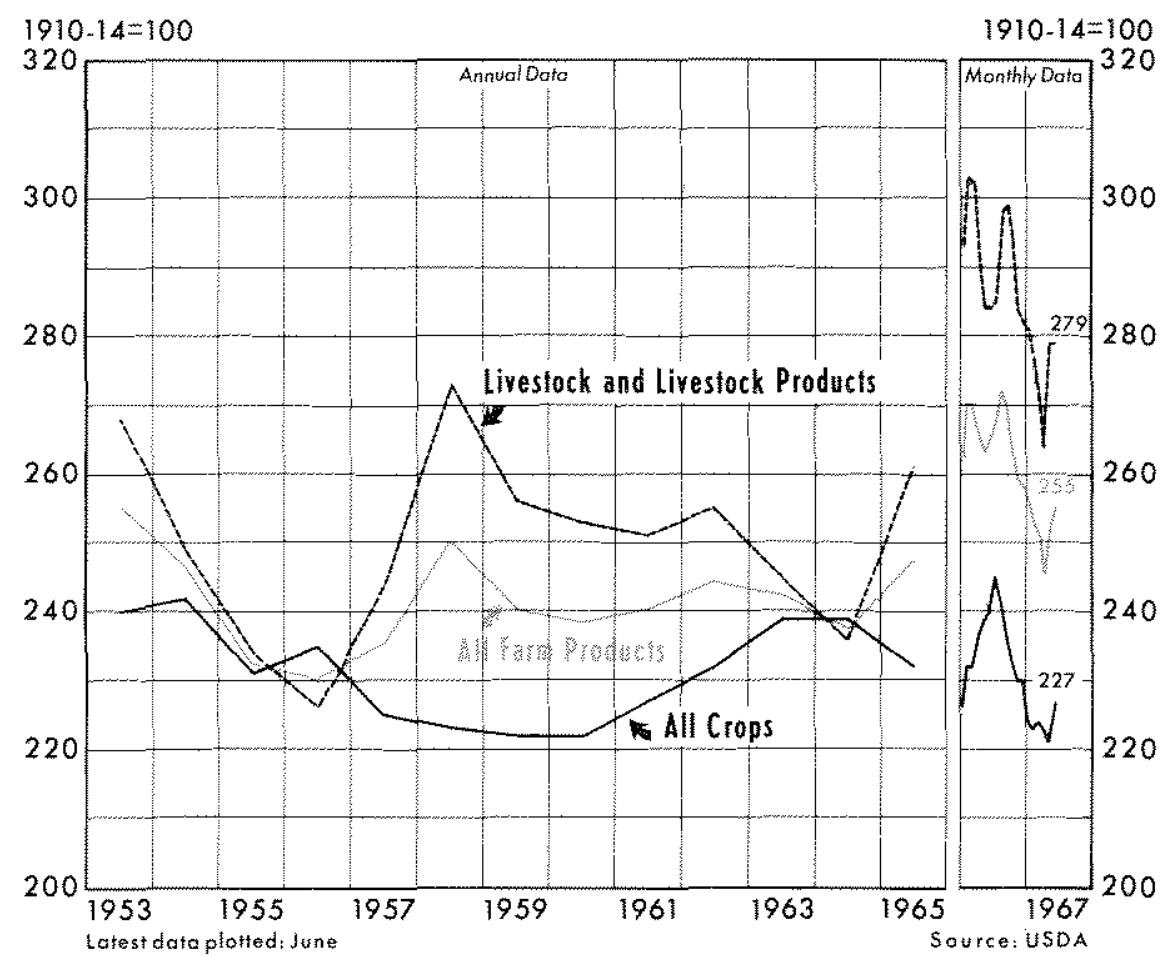


Table III

\section{OUTPUT OF LIVESTOCK PRODUCTS}

\begin{tabular}{|c|c|c|c|}
\hline & $\begin{array}{c}\text { Jan. May } \\
1966 \\
\end{array}$ & $\begin{array}{c}\text { Jon, Mcy } \\
1967\end{array}$ & $\begin{array}{l}\text { Per Cent } \\
\text { Change }\end{array}$ \\
\hline \multicolumn{4}{|l|}{ Dairy Products } \\
\hline Milk, mil. lbs. & 51,729 & 51,822 & 0.2 \\
\hline \multicolumn{4}{|l|}{ Posltry Products } \\
\hline Eggs, mll, doz. & 27,795 & 29,577 & 6.4 \\
\hline Chickens, mil. lbs. ${ }^{\top}$ & 1,835 & 1,987 & 8.3 \\
\hline Turkeys, mil. Ibs, 1 & 91 & 122 & 33.6 \\
\hline \multicolumn{4}{|l|}{ Meat, mil, lbs. } \\
\hline Beef & 7,824 & 8,318 & 6.3 \\
\hline Calf and Yeal & 357 & 308 & -13.7 \\
\hline Pork & 4,443 & 5,165 & 16.3 \\
\hline Lamb and Mution & 264 & 276 & 4.5 \\
\hline Total Red Meot & 12,888 & 14,067 & 9.1 \\
\hline
\end{tabular}

1 January-April data.

Sosrce: USDA Livestock Market New:; Crop Prodsction.

of 1966, whereas spring slaughter was 11 per cent greater, and summer slaughter is also larger.

The number of cattle on feed indicate some decline in fat cattle slaughter during the remaining months of 1967 from the very high rates in the first half of the year. Marketings under Federal inspection during the April-Jume quarter were up 9 per cent from a year ago.

Crop production this year is expected to exceed that of 1966. On the basis of United States Department of Agriculture July 1 estimates and acreage planted data, wheat, corm, and soybean output may exceed the 1966 total by 22, 10, and 9 per cent, respectively (Table IV). Tobacco production may be about 5 per cent higher than the year-earlier level. Output of cotton, oats, and rice may be somewhat lower than last year.

With larger harvests in prospect, crop prices are likely to average a little lower than in 1966. Because of government price supports, however, the price declines will not be great. Hence, increased cash receipts are in prospect as the larger volume of marketings plus government payments will probably more than offset the lower prices. The price received by farmers for wheat (plus marketing certificate payments) is estimated at $\$ 2.23$ per bushel for participating producers, or about 30 per cent above that for the 1965-66 crop. Accordingly, cash receipts for the wheat crop may exceed that for any year since 1947-48. The larger corn crop in prospect may cause prices to decline to about the loan level, which was increased 5 cents per bushel this year to $\$ 1.05$. In addition, the 30 cent per bushel price support payment to cooperating farmers has been retained.

Soybean prices may average somewhat below the $\$ 2.70$ - $\$ 2.80$ per bushel received during the last marketing season. With a record crop in prospect and record farm stocks on hand, totaling 219 million bushels on April 1 , soybean prices may be near the loan rate of $\$ 2.50$ per bushel.

The loan rate for cotton declined somewhat, but the support payment increased, more than offsetting the loan reduction. The burley tobacco loan rate of 61.8 cents per pound is slightly above the 1966 level. The rice loan rate of $\$ 4.55$ per cwt. is also slightly above the year-ago level.

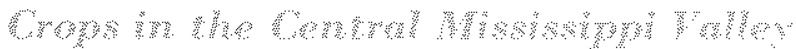

Crop production estimates in the states of the Central Mississippi Valley generally follow the national pattem. ${ }^{2}$ Corn production estimates are substantially higher for three states than last year's output (Table IV). Indicated output is up 11 per cent in Missouri, 26 per cent in Kentucky, and 15 per cent in Tennessee. On the basis of acreage planted, cotton production will be even less than the depressed level of last year. Output of cotton in the area may total less than twothirds the 1961-65 average as crop conditions have generally been poor this year in the upper portion of the Central Belt.

Soybeans continue to replace cotton as a source of farm income in the southern portion of the region. Production may exceed 1966 levels by 8 and 21 per cent in Arkansas and Mississippi, respectively, and Arkansas may for the first time become the leading soybean producing state of the Mississippi Valley group. In contrast to the rapid growth of soybean output in Arkansas, Mississippi, and Tennessee, the size of the crop has tended to stabilize in the northern portion of the region and in Illinois and Indiana.

Burley tobacco production in the region is likely to decline this year, whereas it will remain about the same as last year nationally. Total tobacco production in the nation, however, is expected to increase about 5 per cent. A cold, wet spring, however, retarded plantbed development in Kentucky and resulted in later-than-normal transplanting. Rice production, primarily in Arkansas, is expected to be about the same as in 1966 .

\footnotetext{
2The Central Mississippi Valley comprises five states: Arkansas, Kentucky, Mississippi, Missouri and Tennessee,
} 
Table IV

\section{INDICATED CROP PRODUCTION}

\begin{tabular}{|c|c|c|c|c|c|c|c|c|c|}
\hline & Arkensas & Kentucky & Mississippi & Missouri & Tennessee & $\begin{array}{c}\text { Central } \\
\text { Mississippi } \\
\text { Valley } \\
\end{array}$ & Illinois & Indiana & $\begin{array}{l}\text { United } \\
\text { Stotes } \\
\end{array}$ \\
\hline \multicolumn{10}{|l|}{ Corn } \\
\hline 1967, mil bu. & 2.1 & 82.1 & 14.7 & 196.0 & 42.3 & 337.2 & 996.3 & 473.6 & $4,508.5$ \\
\hline \multicolumn{10}{|l|}{ Per Cent Change } \\
\hline 1966 to 1967 & -12.0 & 26.3 & -6.4 & 11.1 & 14.7 & 13.8 & 19.3 & 19.6 & 9.9 \\
\hline 1961.65 to 1967 & -63.7 & 24.8 & -39.2 & 11.8 & 1.5 & 7.9 & 31.8 & 33.6 & 20.0 \\
\hline \multicolumn{10}{|l|}{ Wheat } \\
\hline 1967, mit bu. & 19.2 & 8.3 & 15.0 & 55.0 & 9.1 & 106.6 & 75.9 & 52.7 & $1,596.1$ \\
\hline \multicolumn{10}{|l|}{ Per Cent Change } \\
\hline 1960 to 1967 & 63.2 & 43.9 & 100.1 & 33.6 & 103,4 & 50.9 & 30.0 & 25.1 & 21.8 \\
\hline $1961-65$ to 1967 & 164.2 & 81.0 & 541.4 & 45.9 & 144,4 & 91.6 & 22.7 & 19.6 & 31.5 \\
\hline \multicolumn{10}{|l|}{ Oats } \\
\hline 1967, mil bu. & 4.1 & 1.0 & 3.1 & 9.0 & 1.9 & 19.1 & 47.6 & 12.8 & 774,2 \\
\hline \multicolumn{10}{|l|}{ Per Cent Change } \\
\hline $\begin{array}{l}1966 \text { to } 1967 \\
1961.65 \text { to } 1967\end{array}$ & $\begin{array}{r}-31.0 \\
23\end{array}$ & $\begin{array}{r}9.1 \\
-15.4\end{array}$ & -8.8 & -8.1 & -12.1 & -14.0 & $\begin{array}{l}-12.6 \\
-337\end{array}$ & $\begin{array}{l}-30.3 \\
-48.5\end{array}$ & $\begin{array}{l}-3.0 \\
-18.8\end{array}$ \\
\hline & & -10.4 & $-2 / .0$ & -20.0 & -26.2 & 10.7 & कon & & \\
\hline \multicolumn{10}{|l|}{ Soybeans } \\
\hline 1967, mil bu. & 90.6 & 9.9 & 52.2 & 87.1 & 27.3 & 267.1 & 157.7 & 73.9 & $10,191.2$ \\
\hline \multicolumn{10}{|l|}{ Per Cent Change } \\
\hline 1966 to 1967 & 8.0 & 27.1 & 21.0 & 2.0 & 28.0 & 10.6 & -1.0 & 1.0 & 9.5 \\
\hline $1961-65$ to 1967 & 29.3 & 64.9 & 75.3 & 27.1 & 101.3 & 42.1 & 2.8 & 4.1 & 35.1 \\
\hline \multicolumn{10}{|l|}{ Rice } \\
\hline 1967, mil. cwl. & 21,0 & - & 2.3 & 0.2 & - & 23.5 & - & - & 84.8 \\
\hline \multicolumn{10}{|l|}{ Per Cent Change } \\
\hline 1966 to 1967 & -0 & - & -4.7 & -0 & - & -0.5 & - & - & -0.3 \\
\hline $1967-65$ to 1967 & 23.0 & - & 30.4 & 22.5 & - & 23.7 & - & - & 24.8 \\
\hline \multicolumn{10}{|l|}{ Tobacco } \\
\hline 1967, mil. lbs. & - & 429.6 & - & 4.8 & 128.6 & 563.0 & - & 14.2 & $1,983.4$ \\
\hline \multicolumn{10}{|l|}{ Per Cent Change } \\
\hline 1966 to 1967 & - & -2.7 & - & -8.2 & 1.1 & -1.9 & - & -4.8 & 4.9 \\
\hline 1961.65 to 1967 & - & -8.7 & - & -13.8 & -12.5 & -9.6 & - & -9.5 & -8.2 \\
\hline \multicolumn{10}{|l|}{ Coltion } \\
\hline 1967, mil. bales & 0.7 & - & 1.3 & 0.4 & 0.3 & 2.7 & - & - & 9.3 \\
\hline \multicolumn{10}{|l|}{ Per Cent Change } \\
\hline 1966 to 1967 & -5.8 & - & -4.7 & $-11,0$ & -18.3 & -7.5 & - & - & -6.0 \\
\hline $1961-65$ to 1967 & -33.8 & - & -36.2 & -40.2 & -38.6 & -36.5 & - & - & -36.6 \\
\hline
\end{tabular}

Sotrce: USDA, 1967 data based on July 1 estimates, Soybean and cotton production estimated on the basis of acreage planted and 1966 yields.

Page 10 